\title{
Teaching Video NeuroImages: A treatable rare cause of chorea
}

Malco Rossi, PhD, Angel Cammarota, MD, Marcelo Merello, PhD, and Martin Nogues, PhD

Neurology ${ }^{\circledR}$ 2018;91:e1089. doi:10.1212/WNL.0000000000006160

A 72-year-old woman developed progressive choreic movements involving the right hemibody and the orofacial muscles (video 1). Her examination was otherwise unremarkable, without ataxia. Brain MRI, blood glucose, thyroid function, and rheumatologic panel were unremarkable. Genetic testing for Huntington disease and C9orf72 expansions were negative. Initial hematocrit and hemoglobin levels were normal, but increased to abnormal values (56\% and $18.5 \mathrm{~g} / \mathrm{dL}$ ) 1 year after chorea onset. The JAK2V617F mutation was positive, suggesting a diagnosis of chorea due to polycythemia vera. Chorea disappeared with phlebotomy and hydroxyurea. Neurologists should suspect this rare treatable entity in elderly patients with chorea even with initially normal hematocrit levels. ${ }^{1}$

\section{Author contributions}

Malco Rossi: study concept and design, acquisition, analysis, and interpretation of data, draft of manuscript. Angel Cammarota: study concept and design, acquisition, analysis, and interpretation of data, draft of manuscript. Marcelo Merello: study concept and design, interpretation of data, critical revision of manuscript for intellectual content. Martin Nogues: study concept and design, interpretation of data, critical revision of manuscript for intellectual content.

\section{Study funding}

No targeted funding reported.

\section{Disclosure}

The authors report no disclosures relevant to the manuscript. Go to Neurology.org/N for full disclosures.

\section{Reference}

1. Bruyn GW, Padberg G. Chorea and polycythaemia. Eur Neurol 1984;23:26-33.

\author{
Correspondence \\ Dr. Rossi \\ mrossi@fleni.org.ar
}

\section{MORE ONLINE}

- Video

$\rightarrow$ Teaching slides

links.lww.com/WNL/

A663 


\section{Neurology}

\section{Teaching Video NeuroImages: A treatable rare cause of chorea Malco Rossi, Angel Cammarota, Marcelo Merello, et al. Neurology 2018;91;e1089 \\ DOI 10.1212/WNL.0000000000006160}

This information is current as of September 10, 2018

\section{Updated Information \& Services}

References

Subspecialty Collections

Permissions \& Licensing

\section{Reprints}

including high resolution figures, can be found at: http://n.neurology.org/content/91/11/e1089.full

This article cites 1 articles, 0 of which you can access for free at: http://n.neurology.org/content/91/11/e1089.full\#ref-list-1

This article, along with others on similar topics, appears in the following collection(s):

Chorea

http://n.neurology.org/cgi/collection/chorea

Clinical neurology examination

http://n.neurology.org/cgi/collection/clinical_neurology_examination Hematologic

http://n.neurology.org/cgi/collection/hematologic

Information about reproducing this article in parts (figures,tables) or in its entirety can be found online at:

http://www.neurology.org/about/about_the_journal\#permissions

Information about ordering reprints can be found online:

http://n.neurology.org/subscribers/advertise

Neurology ${ }^{\circledR}$ is the official journal of the American Academy of Neurology. Published continuously since 1951, it is now a weekly with 48 issues per year. Copyright (O) 2018 American Academy of Neurology. All rights reserved. Print ISSN: 0028-3878. Online ISSN: 1526-632X.

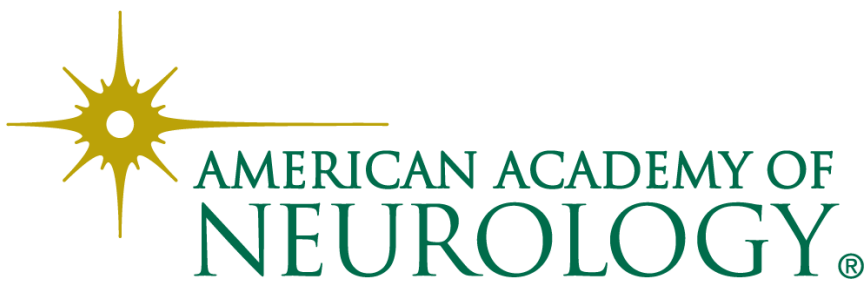

